\title{
Relations between entrapment neuropathies of the lower extremities and Body Mass Index
}

\author{
Alt ekstremite tuzak nöropatileri ve Vücut Kitle İndeksi ilişkisi \\ Dürdane Aksoy*, Hatice Karaer Ünaldı, Betül Çevik, Semiha Kurt, İlker Etikan
}

Department of Neurology (Assist. Prof. D. Aksoy, MD, Assist. Prof. H. K. Ünald1, Assist. Prof. B. Çevik, Assoc. Prof. S. Kurt, MD), Department of Biostatistics (Assist. Prof. İ. Etikan, MD), Gaziosmanpasa University Faculty of Medicine, TR-60100 Tokat

\begin{abstract}
Aims. Peroneal neuropathy, meralgia paresthetica and tarsal tunnel syndrome are the most common entrapment neuropathies of the lower extremities. Although, the effect of Body Mass Index on the entrapment neuropathies of the upper extremities, especially carpal tunnel syndrome, has been studied extensively, its effect on the entrapment neuropathies of the lower extremities, except meralgia paresthetica which is well known to be associated with obesity, is not well understood. In this study, we aimed to investigate the relations between Body Mass Index and the common entrapment neurophaties of the lower extremities. Methods. This retrospective study focused on 204 patients that were referred to our electrophysiology laboratory with a pre-diagnosis of peroneal neuropathy, meralgia paresthetica, and tarsal tunnel syndrome. Each group is separated into two subgroups consisting of patients with and without entrapment neuropathy. Age, sex, and Body Mass Index values are compared amongst the groups. In addition, all of the patients with a pre-diagnosis of entrapment neuropathy are further divided into two subgroups based on their Body Mass Index as 'obese' and 'non-obese' patients, and type and frequency of entrapment neuropathies are investigated. Results. The mean age of the patients pre-diagnosed with entrapment neuropathy was $42.61 \pm 13.75$. There were 97 men and 107 women. Of the 100 patients that were verified to have entrapment neuropathy, 39 were diagnosed with peroneal neuropathy, 39 with meralgia paresthetica and remaining 22 with tarsal tunnel syndrome. $93.8 \%$ of the 'obese' patients who admitted with the pre-diagnosis of meralgia paresthetica were confirmed to have this diagnosis. Body Mass Index values of the patients with verified meralgia paresthetica were significantly higher than those of the patients who were found not to have meralgia paresthetica. There were no significant differences regarding Body Mass Index values between the patients with and without peroneal neuropathy or tarsal tunnel syndrome. Conclusion. It is suggested that meralgia paresthetica is related to high Body Mass Index and obesity. Very limited number of the past studies mentioned associations between high Body Mass Index and tarsal tunnel syndrome, and weight loss and peroneal neuropathy. In this investigation, no significant association was found between obesity or emaciation and peroneal neuropathy or tarsal tunnel syndrome. In addition, the rate of meralgia paresthetica was higher in patients with advanced age, but there was no significant relationship between advancing age and peroneal neuropathy or tarsal tunnel syndrome in this study.
\end{abstract}

Keywords: Lower extremity, Body Mass Index, nerve compression syndromes

\section{Özet}

Amaç. Alt ekstremite tuzak nöropatileri arasında en sık olanlar peroneal nöropati, meralgia parestetica ve tarsal tünel sendromudur. Üst ekstremite tuzak nöropatilerinde özellikle karpal tünel sendromu ile Vücut Kitle İndeksi ilişkisi konusunda pek çok çalışma yapılmış olmasına rağmen alt ekstremitede obeziteyle ilişkisi iyi bilinen meralgia parestetica dışında diğer tuzak nöropatileri ve Vücut Kitle İndeksi ilişkisi belirgin bir şekilde ifade edilmemiştir. Bu çalışmada klinik pratikte sık karşımıza çıkan alt ekstremite tuzak nöropatileri ile Vücut Kitle İndeksi ilişkisini araştırmayı amaçladık. Yöntemler. Bu retrospektif çalışmada elektrofizyoloji laboratuvarımıza peroneal nöropati, meralgia parestetica ve tarsal tünel sendromu ön tanıları ile gönderilen 204 hasta incelendi. Her grup kendi içinde tuzak nöropatisi olan ve olmayanlar olarak ikiye ayrıldı. Yaş, cins ve Vücut Kitle İndeksi değerleri gruplar arasında karşılaştırıldı. Ayrıca tuzak nöropatisi öntanılı tüm hastalar Vücut Kitle İndekslerine göre 'obez' ve 'obez olmayan' şeklinde 2 gruba ayrıldı ve gruplarda tuzak nöropati tipleri ve sıklıkları araştırıldı. Bulgular. Tuzak nöropatisi ön-tanısı ile 


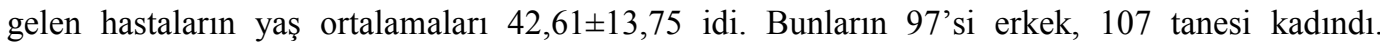
Toplam 204 hastanın 100'ünde tuzak nöropatisi saptandı. Bunların 39 tanesi peroneal nöropati, 39 tanesi meralgia parestetica, 22 tanesi ise tarsal tünel sendromu idi. 'Obez' grubun \%93,8'inde meralgia parestetica ön tanısı teyit edildi. Meralgia parestetica tanısı alan hastaların Vücut Kitle İndeksi değerleri meralgia parestetica'si çıkmayan hastalardan anlamlı derecede daha yüksekti. peroneal nöropati, tarsal tünel sendromu saptanan ve saptanmayan hastalar arasında Vücut Kitle İndeksi değerleri açısından anlamlı bir fark saptanmadı. Sonuç. Meralgia parestetica, yüksek Vücut Kitle İndeksi ve obezite ile belirgin şekilde ilişkilidir. Az sayıda çalışmada tarsal tünel sendromu ile yüksek Vücut Kitle İndeksi birlikteliğinden ve peroneal nöropati ile kilo kaybı ilişkisinden bahsedilmiştir. Bizim çalışmamızda ise peroneal nöropati ve tarsal tünel sendromunun obezite ya da zayıflıkla belirgin ilişkisi saptanmamıştır. Ayrıca çalışmamızda meralgia parestetica oranı yaşla birlikte artış göstermekteydi, ancak bu çalışmada ileri yaş ile peroneal nöropati veya tarsal tünel sendromu arasında anlamlı ilişki saptanmadı.

Anahtar sözcükler: Alt ekstremite, Vücut Kitle İndeksi, sinir basısı sendromları

Geliş tarihi/Received: October 10, 2012; Kabul tarihi/Accepted: January 29, 2013

*Corresponding author:

Dr. Dürdane Aksoy, Nöroloji Anabilim Dalı, Gaziosmanpaşa Üniversitesi Tıp Fakültesi, TR60100 Tokat. E-mail: dbekar@yahoo.com

\section{Introduction}

Entrapment neuropathy is defined as pressure damage, which develops in any segment along a peripheral nerve and caused by the anatomic structures or pathological processes [1-3]. Every peripheral nerve has some anatomic areas where it is sensitive or vulnerable $[3,4]$. For instance, in the carpal tunnel syndrome (CTS) this area is the transverse carpal ligament, where the median nerve frequently gets injured $[3,5,6]$.

In entrapment neuropathies, etiology has wide variation based on the anatomic trace of each nerve, physical properties, personal and occupational habits of the patient $[3,6,7]$. Numerous studies have investigated and determined a relation of obesity especially with CTS, which is one of the upper extremity entrapment neuropathies [7-11]. Likewise, a triggering effect of obesity on the cubital tunnel syndrome was reported [12, 13].

On the other hand, among the lower extremity entrapment neuropathies, the relation of meralgia paresthetica (MP) with obesity is well known [14-17]. Along with hypothyroidism and diabetes, the obesity is regarded as one of the systemic reasons of tarsal tunnel syndrome (TTS) $[18,19]$.

It has been determined that, peroneal neuropathy $(\mathrm{PN})$, which is the most frequentlyencountered lower extremity entrapment neuropathy, is associated with serious short-term weight losses or emaciation, such as anorexia nervosa [20-24].

This retrospective study investigated the relation between the lower extremity entrapment neuropathies such as PN, MP and TTS, which are frequently encountered in clinical practice, and the body mass index (BMI) and effect of obesity or emaciation on susceptibility towards the entrapment neuropathy.

\section{Material and methods}

\section{Standardization of diagnoses}

In the electrophysiology laboratories of the Neurology Department of our hospital, the patients, who were admitted with a pre-diagnosis of entrapment neuropathy, are diagnosed and reported to have entrapment neuropathy within the scope of the protocols applied as described below. Nerve conduction studies are conducted using the MedelecOxford Synergy electromyography (EMG) device (Oxford Instruments Medical, Surrey, UK). Extremity temperatures are kept above $31^{\circ} \mathrm{C}$. 
PN: Diagnosis of 'Common Peroneal Nerve Entrapment Neuropathy' was established in case of the retardation of motor conduction rate of peroneal nerve in the capitulum fibulafossa popliteal segment, decrease in the amplitude of $\mathrm{M}$ response, record of neurogenic changes on tibialis anterior and extensor digitorum brevis muscles in needle EMG, and abnormality of superficial peroneal nerve sensory response [25, 26].

MP: While investigating the lateral femoral cutaneous nerve entrapment neuropathy, the method of needle placement near the nerve was used. In this orthodromic method, the nerve was stimulated in $12 \mathrm{~cm}$ distal of the spina iliac anterior superior from the frontal leg and a recording was received from the area that was previously determined around $1 \mathrm{~cm}$ medial of the spina iliac anterior, with the help of a teflon-coated needle electrode. The diagnosis of MP was gotten in case that lateral femoral cutaneous nerve sensory response latency was extended or could not be taken.

TTS: As defined by Falck, in this entrapment neuropathy where the posterior tibial nerve was injured in the line of ankle, the motor conductions of tibial nerve, medial plantar nerve and lateral plantar nerve were examined. In case that no abnormalities was determined in these conductions, interdigital plantar nerve sensory conductions were examined using the method of needle placement near the nerve. TTS was diagnosed in case that any abnormality was determined during any of these conductions [26].

Two hundreds and four patients, who were admitted to our electrophysiology laboratory between 2006 and 2011 with the pre-diagnoses of PN, MP and TTS, were included into the study. The heights and weights of the patients were recorded, Among these patients, those who were diagnosed with entrapment neuropathy after the EMG in line with the above-described criteria and whose electrophysiological findings were normal, were examined and compared with eachother. At the end of the EMG, patients with different diagnoses, such as polyneuropathy, radiculopathy or myopathy, or with an additional abnormality on any nerve or muscle, except for the tibial nerve for TTS, peroneal nerve for PN and lateral femoral cutaneous nerve for MP, were not included into the study.

BMI was obtained by dividing the body weight into the square of stature. While those having BMIs of $30 \mathrm{~kg} / \mathrm{m}^{2}$ and above were defined as 'obese', those below this value were defined as 'non-obese'. Groups with a pre-diagnoses of PN, MP and TTS were separated into two groups as obese and non-obese, in line with the definition above.

\section{Statistical evaluation}

Chi-square test was used to compare the qualitative variables. In addition, odd's Ratio's on risk factors were also calculated. Additionally, independent samples t test was used for comparison of continuous variables. Normal distributions of variables were examined with the Kolmogorov-Smirnov normal distribution test. For patients with PN, MP and TTS, the relationship between age and BMI were analyzed with Pearson correlation coefficient. When the $\mathrm{P}$ values were calculated below 0.05 , it was accepted to be statistically significant. The off-the-shelf statistics software (IBM SPSS Statistics 19, SPSS inc., an IBM Co., Somers, NY) was used to make calculations.

\section{Results}

Out of 204 patients who were admitted with the pre-diagnosis of lower extremity entrapment neuropathy, 107 were women and 97 were men. There was no difference in the distribution of entrapment neuropathy, in terms of gender. The ages of patients were between 19 and 78, and their mean age was $42.61 \pm 13.75$.

Table 1 illustrates the mean age and BMIs of the patients with pre-diagnosis of entrapment neuropathies (Table 1). The diagnosis of entrapment neuropathy was verified for 39 of the 80 patients with PN pre-diagnosis, 39 of the 53 patients with MP prediagnosis, 22 of the 71 patients with TTS pre-diagnosis. 
Table 1. Mean age and Body Mass Index (BMI) of all of the patients with pre-diagnosis of entrapment neuropathy.

\begin{tabular}{lll}
\hline & $\begin{array}{l}\text { Age } \\
\text { Mean } \pm \text { SD }\end{array}$ & $\begin{array}{l}\text { BMI } \\
\text { Mean } \pm \text { SD }\end{array}$ \\
\hline Pre-diagnosis of PN $(\mathrm{n}=80)$ & $40.23 \pm 15.56$ & $27.09 \pm 5.79$ \\
Pre-diagnosis of MP $(\mathrm{n}=53)$ & $42.65 \pm 14.36$ & $27.31 \pm 5.04$ \\
Pre-diagnosis of TTS $(\mathrm{n}=71)$ & $45.76 \pm 10.86$ & $29.29 \pm 5.37$ \\
\hline Total $(\mathrm{n}=204)$ & $42.61 \pm 13.75$ & $27.92 \pm 5,51$ \\
\hline
\end{tabular}

PN: Peroneal neuropathy, MP: Meralgia paresthetica, TTS: Tarsal tunnel syndrome

Patients were assessed according to their sub-types of neuropathy as follows: among the patients with pre-diagnosis of PN; PN was verified in 55.2\% of the 'non-obese group' and $31.8 \%$ of the 'obese group'. The 'non-obese group' had a greater percentage of PN, however it was not statistically significant $(\mathrm{p}=0.062)$ (Table 2). Out of 53 patients who was admitted to our laboratory with the pre-diagnosis of MP, 16 were obese and $93.8 \%$ of this group was diagnosed with MP. MP diagnosis was also verified in $64.9 \%$ of 'nonobese' group. This difference was statistically significant $(p=0.029)$ (Table 2 ). Regarding those who was admitted with the pre-diagnosis of TTS, there was no significant difference between the 'obese' and 'non-obese' groups, in terms of TTS rate (Table 2).

Table 2. Entrapment neuropathy development rates of 'non-obese' and 'obese' groups prediagnosed with entrapment neuropathy.

\begin{tabular}{|c|c|c|c|c|c|c|}
\hline & \multicolumn{2}{|c|}{ 'Non-obese' Group } & \multicolumn{2}{|c|}{ 'Obese' Group } & \multirow[b]{2}{*}{$\mathbf{p}$} & \multirow{2}{*}{ OR (0.95 CI $)$} \\
\hline & Number & $\%$ & Number & $\%$ & & \\
\hline Peroneal neuropathy $(+)$ & 32 & 55.2 & 7 & 31.5 & \multirow{2}{*}{0.062} & \\
\hline Peroneal neuropathy (-) & 26 & 44.8 & 15 & 68.2 & & \\
\hline Meralgia paresthetica $(+)$ & 24 & 64.9 & 15 & 68.2 & \multirow{2}{*}{0.029} & \multirow{2}{*}{$8.12[0.962-8.631]$} \\
\hline Meralgia paresthetica (-) & 13 & 35.1 & 1 & 6.2 & & \\
\hline $\operatorname{TTS}(+)$ & 13 & 30.2 & 9 & 32.1 & \multirow{2}{*}{0.865} & \\
\hline TTS (-) & 30 & 69.8 & 19 & 67.9 & & \\
\hline
\end{tabular}

TTS: Tarsal tunnel syndrome

Mean BMI of all patients, who was admitted to our laboratory with the suspicion of entrapment neuropathy, was determined as $27.92 \pm 5.51$. BMIs of those diagnosed with MP were significantly higher in comparison to those who were not diagnosed with MP $(\mathrm{p}=0.011)$. There was no significant difference between the BMIs of patients with and without PN or TTS (Table 3).

Table 3. Comparison of patients with and without entrapment neuropathy according to their Body Mass Index (BMI).

\begin{tabular}{llcc}
\hline & $\begin{array}{l}\text { BMI } \\
\text { Means } \pm \text { SD }\end{array}$ & t & p \\
\hline Peroneal neuropathy (+) & $26.33 \pm 5.17$ & 1.160 & 0.240 \\
Peroneal neuropathy (-) & $27.83 \pm 6.30$ & & \\
\hline Meralgia paresthetica (+) & $28.35 \pm 4.96$ & 2.647 & 0.011 \\
Meralgia paresthetica (-) & $24.41 \pm 4.58$ & & \\
\hline Tarsal tunnel syndrome (+) & $30.71 \pm 5.84$ & 0.135 & 0.135 \\
Tarsal tunnel syndrome (-) & $28.65 \pm 5.08$ & & \\
\hline
\end{tabular}

When all of the patients with the pre-diagnosis of entrapment neuropathy were compared regarding their ages, there was no significant difference between the ages of the patients with and without PN or TTS, but ages of those diagnosed as MP were significantly higher in comparison to those who were not diagnosed as MP $(\mathrm{p}=0.003)$ (Table 4). 
Table 4. Comparison of the patients with entrapment neuropathy according to their Ages.

\begin{tabular}{llllll}
\hline & Number (n) & $\begin{array}{c}\text { Age } \\
(\mathbf{M e a n} \pm \text { SD) }\end{array}$ & t & p \\
\hline Peroneal neuropathy (+) & 39 & $41.32 \pm 17.21$ & 0.629 & 0.531 \\
Peroneal neuropathy (-) & 41 & $39.15 \pm 13.84$ & & \\
\hline Meralgia paresthetica (+) & 39 & $46.00 \pm 13.61$ & 3.130 & 0.003 \\
Meralgia paresthetica (-) & 14 & $33.07 \pm 12.30$ & & \\
\hline Tarsal tunnel syndrome (+) & 22 & $44.82 \pm 10.79$ & 0.481 & 0.632 \\
Tarsal tunnel syndrome (-) & 49 & $46.15 \pm 10.97$ & & \\
\hline
\end{tabular}

\section{Discussion}

Among the lower extremity entrapment neuropathies, PN is the most frequently encountered entrapment neuropathy in the clinic and constitutes $15 \%$ of all mononeuropathies $[24,27]$. The relation of peroneal nerve paralysis and weight loss is remarkable and some studies concluded that rapid and important weight losses cause peroneal nerve lesion [20-23, 28]. Weight losses caused by psychiatric disorders, such as anorexia nervosa, diet, gastric bandage, and or other serious diseases such as cancer, diabetes, and pneumonia increase the risk of PN [24, 28, 29]. It is suggested to investigate whether there is a fast and unregulated weight loss especially in patients who come with a foot drop [16, 19]. In this study, the development rate of PN was higher in the "nonobese' group. Besides, the BMIs of the patients with PN were moderately lower compared to those without PN. The reason for this condition might be the fact that we separated the patients only into 2 groups according to their BMIs, in order to conduct the convenient statistical analyses. In addition, PN was reported in patients who had experienced serious weight losses within a short time, rather than those who have been slim for a long time [22, 28, 29]. We did not question the changes in the body weight of the patients that had experienced for the last few months.

A study conducted in recent times determined that MP frequency is greater in obese, diabetics and advanced age group [30]. In our study, similar to these findings, the rate of MP increases with the advanced age. Age of the patients with MP were significantly higher than that of the patients without MP. The relation of MP with obesity was emphasized in other studies, as well [14-17, 31]. It was reported that obesity doubles the development risk of MP and that MP adversely affects the post-surgical treatment recovery $[16,32]$. Due to this well-known relation of MP with obesity, it is suggested for patients to reduce weight for the conservative treatment of the disease [33, 34]. In our study, the rate of MP was more distinct in the 'obese' group. Additionally, patients with MP had higher mean BMI in comparison to those without MP.

Trauma on the ankle, ganglion cysts, neurilemomas or other tumoral lesions, hypertrophic or accessory muscles, enlarged venous structures, hypertrophic flexor retinaculum and foot deformities are in the etiology of the TTS [3, 35-39]. Additionally, it was reported that as well as gout, diabetes mellitus, rheumatoid arthritis, ankylosing spondylitis, acromegaly and hypothyroidism, the obesity enables developing TTS [41]. Besides, rapid weight gain was also mentioned among the reasons of TTS [35-41]. Similarly, regarding the treatments of TTS, it is recommended for patients to lose weight, before surgical and medical treatments [40]. In our study, the BMIs of patients with TTS were slightly higher than those without TTS.

Regarding the diagnosis of lower extremity entrapment neuropathy, we believe that along with many etiological factors, such as the age, occupation, other present diseases and life style of the patient, their state of being over-weight or slim is also important in terms of directing the clinician. The rate of MP was higher in elderly patients, but there was no significant relationship between advancing age and PN or TTS in our study. The association of MP, which is one of frequently-encountered neuropathies of the lower extremity, with obesity is clear. Our findings support this, as well. However, we may 
have not explicitly emphasized the association of PN with emaciation, possible relation of TTS with obesity, due to the insufficient number of patients. As a consequence, new studies that include broad patient and control groups are required to determine the relations of both PN and TTS with the body weight.

\section{References}

1. Beltran LS, Bencardino J, Ghazikhanian V, Beltran J. Entrapment neuropathies III: Lower limb. Semin Musculoskelet Radiol 2010; 14: 501-11.

2. Koppel HP, Thompson WA. Peripheral entrapment neuropathies of the lower extremity. N Eng J Med 1960; 262: 56-60.

3. Toussaint CP, Perry EC 3rd, Pisansky MT, Anderson DE. What's new in the diagnosis and treatment of peripheral nerve entrapment neuropathies. Neurologic Clinics 2010; 28: 979-1004.

4. McCluskey LF, Webb LB. Compression and entrapment neuropathies of the lower extremity. Clin Podiatr Med Surg 1999; 16: 97-125.

5. Atroshi I, Gummesson C, Johnsson R, Ornstein E, Ranstam J, Rosén I. Prevalence of carpal tunnel syndrome in a general population. JAMA 1999; 282: 153-8.

6. Weyns FJ, Beckers F, Vanormelingen L, Vandersteen M, Niville E. Foot drop as a complication of weight loss after bariatric surgery: is it preventable? Obes surg 2007; 17: 1209-12.

7. Boz C, Ozmenoglu M, Altunayoglu V, Velioglu S, Alioglu Z. Individual risk factors for carpal tunnel syndrome: an evaluation of body mass index, wrist index and hand anthropometric measurements. Clin Neurol Neurosurg 2004; 106: 2949.

8. Werner RA, Albers JW, Franzblau A, Armstrong TJ. The relationship between body mass index and the diagnosis of carpal tunnel syndrome. Muscle Nerve 1994; 17: 632-6.

9. Becker J, Nora DB, Gomes I, Stringari FF, Seitensus R, Panosso JS, Ehlers JC. An evaluation of gender, obesity, age and diabetes mellitus as risk factors for carpal tunnel syndrome. Clin Neorophisiolog 2002; 113: 1429-34.

10. Kurt S, Kisacik B, Kaplan Y, Yildirim B, Etikan I, Karaer H. Obesity and carpal tunnel syndrome: is there a causal relationship? Eur Neurol 2008; 59: 253-7.

11. Moghtaderi A, Izadi S, Sharafadinzadeh N. An evaluation of gender, body mass index, wrist circumference and wrist ratio as independent risk factors for carpal tunnel syndrome. Acta Neurol Scand 2005; 112: 375-9.

12. Cutts S. Cubital tunnel syndrome. Postgrad Med J 2007; 83: 28-31.

13. Descatha A, Leclerc A, Chastang JF, Roquelaure Y; Study Group on Repetitive Work. Incidence of ulnar nerve entrapment at the elbow in repetitive work. Scand J Work Environ Health 2004; 30: 234-40.

14. Ivins GK. Meralgia paresthetica, the elusive diagnosis: clinical experience with 14 adult patients. Ann Surg 2000; 232: 281-6.

15. Nouraei SA, Anand B, Spink G, O'neill KS. A novel approach to the diagnosis and management of meralgia paresthetica. Neurosurgery 2007; 60: 696-700.

16. Siu TL, Chandran KN. Neurolysis for meralgia paresthetica: an operative series of 45 cases. Surgical Neurology 2005; 63: 19-23.

17. Williams PH, Trzil KP. Management of meralgia paresthetica. J Neurosurg 1991; 74: 76-80.

18. Stuart JD, Morgan RF, Persing JA. Nerve compression syndromes of the lower extremity. Am Fam Physcian 1989; 40: 101-12.

19. Yalıman A. Causes of foot pains extra joints. T Klin J PM \& R-Special Topics 2010; 3: 22-30.

20. Baima J, Krivickas L. Evaluation and treatment of peroneal neuropathy. Curr Rev Musculoskelet Med 2008; 1: 147-53.

21. Cruz-Martinez A, Arpa J, Palau F. Peroneal neuropathy after weight loss. J 
Peripher Nerv Sys 2000; 5: 101-5.

22. Elias WJ, Pouratian N, Oskouian RJ, Schirmer B, Burns T. Peroneal neuropathy following successful bariatric surgery. Case report and review of the literature. J Neurosurg 2006; 105: 631-5.

23. Shahar E, Landau E, Genizi J. Adolescence peroneal neuropathy associated with rapid marked weight reduction: case report and literature review. Eur J Paediatr Neuorol 2007; 11: 50-4.

24. Aprile I, Caliandro P, Giannini F, Mondelli M, Tonali P, Foschini M, Padua L; Italian CTS and other entrapments Study Group. Italian multicentre study of peroneal mononeuropathy at the fibular head: study design and preliminary results. Acta Neurochir Suppl. 2005; 92: 63-8.

25. Ertekin C. Lumbosakral Pleksustan Çıkan Sinirler. Sentral ve Periferik EMG anatomi- fizyoloji- klinik. 1st ed. İzmir, Metabasım 2006; pp: 483-99.

26. Oh S J. Clinical Electromyography Nerve Conduction studies. 3rd ed. Philadelphia, Williams \& Wilkins; 2003; pp: 216-48.

27. Cokluk C. Lower extremity entrapment neuropathies. T Klin J Neurosurg 2010; 3: $37-45$.

28. Lutte I, Rhys C, Hubert C, Brion F, Boland B, Peeters A, Van Den Bergh P, Lambert M. Peroneal nerve palsy in anorexia nervosa. Acta Neurol Belg 1997; 97: 251-4.

29. Kershenbaum A, Jaffa T, Zeman A, Boniface S. Bilateral foot-drop in a patient with anorexia nervosa. Int J Eat Disord 1997; 22: 335-7.

30. Parisi TJ, Mandrekar J, Dyck PJ, Klein CJ. Meralgia paresthetica: Relation to obesity, advanced age, and diabetes mellitus. Neurology 2011; 77: 1538-42.

31. Macgregor AM, Thoburn EK. Meralgia paresthetica following bariatric surgery. Obes Surg 1999; 9: 364-8.

32. Mondelli M, Rossi S, Romano C. Body mass index in meralgia paresthetica: a case-control study. Acta Neurol Scand 2007; 116: 118-23.

33. Moucharafieh R, Wehbe J, Maalouf G. Meralgia paresthetica: a result of tight new trendy low cut trousers ('taille basse'). Int J Surg 2008; 6: 164-8.

34. Ay A, Sagirkaya Z, Yurtkuran M. A case with meralgia paresthetica. T Klin J PM\&R 2004; 4: 21-4.

35. Cimino WR. Tarsal tunnel syndrome: review of the literature. Foot Ankle 1990: 11: 47-52.

36. Franson J, Baravarian B. Tarsal tunnel syndrome: A compression neuropathy involving four distinct tunnels. Clin Podiatr Med Surg 2006; 23: 597-609.

37. Lau JT, Daniels TR. Tarsal tunnel syndrome: a review of the literature. Foot Ankle Int 1999; 20: 201-9.

38. Low HL, Stephenson G. These boots weren't made for walking: tarsal tunnel syndrome. CMAJ 2007; 176: 1415-6.

39. Ak F, Ardicoglu O, Nurlu G, Karaoglan B, Saka M, Ayhan Ardıc F. The electroneurophisiological findings in clinicaly suggested tarsal tunnel syndrome patients.T Klin J Med Sci 1996; 16: 148-51.

40. Cancilleri F, Ippolito M, Amato C, Denaro V. Tarsal tunnel syndrome: Four uncommon cases. Foot and Ankle Surgery 2007; 13: 214-7.

41. Lau JT, Stavrou P. Posterior tibial nerve--primary. Foot Ankle Clin 2004; 9: 27185. 